\title{
STRATEGY «ONE BELT-ONE ROAD»AND ITS INFLUENCE ON THE DEVELOPMENT OF HIGHER EDUCATION IN CHINA
}

\author{
Yang Zhuang \\ H. S. Skovorody Kharkiv National Pedagogical University, \\ Valentinivs'ka street, 2, Ukraine, 61000 \\ yangzhuanghnpu@gmail.com, ORCID: https://orcid.org/0000-0002-2238-6819
}

\begin{abstract}
The article highlights main points of One Belt-One Road strategy, which is relevant in China today. Although this strategy is targeted, first of all, at the development of economic activities of the country it has a great effect on the system of education as well. The purpose of the article is to present the essence of the strategy "One Belt -One Road" in order to understand the changes, which are happening in the Chinese society and its system of higher education. During the work on the article, the methods of critical analysis of scientific literature, the method of systematizing and generalizing the information on the strategy "One Belt-One Road" were used. In the process of research it was found out that the "path of civilization" plays a crucial role in the implementation of this strategy. A new set of tasks which has an influence on the education is presented (creation of a multilevel mechanism for humanitarian cooperation and development of even more platforms for cooperation with strategic partners; promotion of educational cooperation, expansion of mass student exchange, increase of the level of joint newly created educational institutions; usage of the role of think tanks, creation of an alliance and network of think tank collaboration; creation of a new model of collaboration in the spheres of culture, sports, and health; usage of the historical cultural heritage). On the analysis of the main points of the strategy it was concluded that "One Belt-One Road" strategy in educational areas is reflected in three main directions (internalization of the educational system in the country; new approaches to the formation of the specialists to be; high requirements to academic staff of higher institutions of China). The analyses of each of the highlighted directions is given.
\end{abstract}

Key words: One Belt-One Road Strategy, education, internalization, new approaches to teaching, requirements to academic staff

\section{Ян Чжуан}

Харківський національний педагогічний університет імені Г. С. Сковороди,

Вул. Валентинівська 2, Україна, 61000

\section{СТРАТЕГІЯ «ОДИН ПОЯС-ОДИН ШЛЯХ» ТА ІІЇ ВПЛИВ НА РОЗВИТОК ВИЩОї ОСВІТИ В КИТАЇ}

У статті представлено ключові елементи стратегії «Один пояс - один шлях», яка актуальна сьогодні в Китаї. Хоча ця стратегія орієнтована, перш за все, на розвиток економічної діяльності країни, вона має великий вплив і на систему освіти. Мета статті - висвітлити суть стратегії «Один пояс - один шлях», щоб зрозуміти зміни, що відбуваються у китайському суспільстві та системі вищої освіти. Під час роботи над статтею були використані методи критичного аналізу наукової літератури, метод систематизації та узагальнення інформації щодо стратегії «Один пояс - один шлях». У процесі досліджень було встановлено, що “шлях цивілізації" відіграє вирішальну роль у реалізації цієї стратегії. Представлено новий комплекс завдань у рамках цієї стратегії, що впливає на освіту (створення багаторівневого механізму гуманітарної співпраці та розвиток ще більшої кількості платформ для співпраці зі стратегічними партнерами; сприяння освітній співпраці, розширення масового обміну студентами, підвищення рівня викладання у навчальних закладах; підвищення ролі аналітичних центрів, створення альянсу та мережі співпраці аналітичних центрів; створення нової моделі співпраці у сферах культури, спорту та охорони здоров'я; використання історичної культурної спадщини). На основі аналізу основних пунктів стратегії було зроблено висновок, що стратегія «Один пояс - один шлях» в освітніх сферах відображається у трьох основних напрямках (інтерналізація освітньої системи в країні; нові підходи до формування майбутніх фахівців; високі вимоги до викладачів вищих навчальних закладів Китаю). Представлено аналіз кожного із зазначених напрямків.

Ключові слова: Стратегія «Один пояс - один шлях», освіта, інтерналізація, нові підходи до викладання, вимоги до викладачів 
2021 Випуск/ Issue 48

\section{Ян Чжуан}

Харьковский национальный педагогический университет имени Г. С. Сковороды, ул. Валентиновская, 2, Украина, 61000

\section{СТРАТЕГИЯ «ОДИН ПОЯС-ОДИН ПУТЬ» И ЕЕ ВДЛИЯНИЕ НА РАЗВИТИЕ СИСТЕМЫ ВЫСШЕГО ОБРАЗОВАНИЯ В КИТАЕ}

В статье освещены основные положения стратегии «Один пояс, один путь», актуальной сегодня в Китае. Хотя эта стратегия нацелена, прежде всего, на развитие экономической деятельности страны, она оказывает большое влияние и на систему образования. Цель статьи - представить суть стратегии «Один путь - один путь», чтобы понять изменения, которые происходят в китайском обществе и системе высшего образования. При работе над статьей использовались методы критического анализа научной литературы, метод систематизации и обобщения информации по стратегии «Один пояс - один путь». В процессе исследования выяснилось, что «путь цивилизации» играет решающую роль в реализации этой стратегии. Представлен новый набор задач, влияющих на образование (создание многоуровневого механизма гуманитарного сотрудничества и развитие еще большего числа платформ для сотрудничества со стратегическими партнерами; продвижение образовательного сотрудничества, расширение обмена студентами, повышение уровня преподавания в учебных заведенях; использование роли аналитических центров, создание альянса и сети сотрудничества аналитических центров; создание новой модели сотрудничества в сферах культуры, спорта и здоровья; использование историко-культурного наследия). На основе анализа основных положений стратегии был сделан вывод, что стратегия «Один пояс - один путь» в сфере образования отражена в трех основных направлениях (интернализация образовательной системы в стране; новые подходы к формированию будущих специалистов; высокие требования к профессорско-преподавательскому составу высших учебных заведений Китая). Представлен анализ каждого из выделенных направлений.

Ключевые слова: стратегия "Один пояс - один путь», образование, интернализация, новые подходы к обучению, требования к преподавательскому составу.

Formulation of the problem. The new paradigm of education, which is being established in the world at the beginning of the XXI-st century, is connected with the rethinking of the role of higher education in the educational system of China as well, as it is important to understand and analyze the ways of the formation of highly qualified specialists who are able to think creatively and approach the organization of work in a non-standard way.

Particular attention to the training of highly qualified specialists is also connected with the successful implementation of the "One Belt-One Road" strategy, which opens up new opportunities for the development of cooperation between China and other countries, spreading Chinese culture and strengthening the sharing experience between other nations.

Analysis of the main research and publications in which the problem is solved has shown that the strategy "One Belt -One Road" is of interest for scientists. Thus, Chen Syue and Tsiyu Minfen investigated opportunities and challenges in promoting the «One belt, one road» initiative in China, Li Sinjun studies some difficulties, which face Chinese educational establishments when implementing "One BeltOne Road" strategy, Huan Luntan researched the place of soft force in the framework of this theory,
Bay Lu investigated the role on internalization in higher education of China. However, scientific literature lacks works, reflecting the changes which should take place in the system of higher education of China.

Purpose of the publication is to highlight the essence of the strategy "One Belt-One Road" in order to understand the changes, which are happening in the Chinese society and its system of higher education. This calls for the of the following solution of the following objectives:

to define the main essence and principles of the strategy "One Belt-One Road";

to analyze the effect of this strategy on the development of the system of higher education in China.

Research methods. During the work on the article, the methods of critical analysis of scientific literature, the method of systematizing and generalizing the information on the strategy "One Belt-One Road" were used. These approaches helped identify the features of the phenomena under consideration and the ways of the development of the system of higher education in China.

The results. The state strategy of the development "One Belt- One Road" is the result of changing the nature and essence of international economic relations as well as China's international 
commitment and implementation of Chinese traditional country in international social and economic development. This strategy includes "Economic Belt of the Silk Road" and "Maritime Silk Road of the XXI-st century" [3, p. 7].

We shall mention that One Belt- One Road Initiative is a development concept of cooperation, and not the traditional model of development of real economics. It entirely relies on the bilateral collaboration of China with its business partners and adheres to the principle of peaceful development, actively develops forging economic partnerships with countries, which are part of this initiative.

It also jointly creates a community of interests of mutual trust, economic integration, which encompasses the spheres of culture, community responsibility, and community destiny. With the gradual advancement of the One Belt-One Road initiative, countries that rarely cooperated before, and countries that cooperate strengthened their cooperation even more. As of January 2018, over 100 countries and international organizations participated in various projects and programs which were initiated by "One Belt- One Road" strategy [1].

In May 2017, Beijing hosted a high-level forum devoted to the development of the Belt and Road initiative, where a lot of representatives from different countries were invited. This event promoted the strategy on the new stage, turning it into a wider large-scale international undertaking.

The definition of a new stage in the development of the "One Belt- One Road" strategy was presented in the Xi Jinping's speech on May 14, 2017, where he analyzed its achievement and outlined main vectors of its development. It should be noted that the fifth element of this strategy is devoted to the "Interconnection of human hearts" and is considered to be a "humanity basket" in the frames of this strategy.

Xi Jinping pointed out that since 2013 the countries, taking part in this initiatives and launching it, have developed collaboration not only in business, but in the fields of education, culture, health care system as well. This strategy has allowed developing exchange programs between nations, creating strong basis in public opinion. The leader announced that every year they gave 10 thousand special scholarships for the countries of the Silk Road. The authorities of the Chinese Republic encouraged the organization of people's cultural and educational exchanges, festivals of cinema and art, conferences and dialogues of think tanks as well.

In his speech Xi Jinping introduced an updated set of tasks, targeting on the construction of the "path of civilization", which means:

- the creation of a multilevel mechanism for humanitarian cooperation and development of even more platforms for cooperation with strategic partners;

- the promotion of educational cooperation, expansion of mass student exchange, increase of the level of joint newly created educational institutions;

- the usage of the role of think tanks, creation of an alliance and network of think tank collaboration;

- the creation of a new model of collaboration in the spheres of culture, sports, and health;

- the usage of the historical cultural heritage [8].

Scientists point out that China has rich cultural resources, but it has not learned how to turn them into "soft power" so far, as the country doesn't have the right media tools for its transmission to foreign partners, as well as the experience of using the potential of non-governmental organizations in this area.

In order to solve this problem it was recommended to create Silk Road Cultural Development Fund. Its main target is to help Chinese cultural enterprises make investments and commercial acquisitions in the countries, which are the partners of the "One-Belt-One Road" strategy, support international cultural forums, promote exchanges folk cultures and develop cultural tourism, support the creation of works of art and cinema, preserve the historical traces of the culture of the Silk Road.

This structure is also targeted at the cultural influence on other countries, relying on economic levers and support of the state. This example shows that during the implementation of the "One Belt-One Road" project, the Chinese side promotes culture and its values, complete with political ideas, seeks to acquire influence on the elites of other countries in order to encourage them to make appropriate decisions [9].

Some Chinese scientists suggest using the ideas of traditional Confucianism, which have an attractive humanistic content, as a support for cultural advancement in the countries-partners of the "One Road-One Belt" strategy. Sun Dajun 
(School of Cultural Creativity and Communication of Huainan Pedagogical Institute) advises to unite the countries, using the culture of a "noble man". Its founders were the ancient sages Confucius and Mengzi, and this ideas include the ethical norms of Confucianism.

The character of the "noble man" should combine self-improvement and the aspiration to put in order the family and the state, honesty and deception in relations with people. This set of four values also reminded in his speech Xi Jinping in October 2013 at a meeting on diplomatic work with neighboring countries.

Another variant of the Confucian model of cooperation in "One Belt-One Road" puts the path of "devotion and generosity". These ethical values were formulated in the text "Lunyu". "Devotion" requires helping other people to get the same achievements that the individual does, and "generosity" means not to do to other people what you do not want yourself.

An important idea of respect and dignity for partners is rooted in the Confucian "way of devotion and generosity", which is the" golden rule " in order to achieve the unification of human hearts. If, on the basis of Confucian ethics, people should consciously care for other people and protect their interests, it will be possible to reduce hostility and conflicts. The implementation of the One Belt-One Road initiative should help encourage other people to "get on their feet" without harming them.

Li Shihe and Xu Jiuping believe that the Silk Road needs the Confucian spirit of equality, inclusiveness, humanity and good deeds for other people. They note that the desire to "do good to Celestial Empire" in Chinese culture initially means international cooperation.

Summing up, we shall note that the implementation of the strategy "One Belt-One Road" in educational area is reflected in three main directions:

- internalization of the educational system in the country;

- new approaches to the formation of the specialists to be;

- high requirements to academic staff of higher institutions of China.

As it stands today, one of the main tasks of the Chinese higher education system is the internationalization of education which should be effectively integrated into the education system in most higher education institutions.
The central goal of this process is to educate highly qualified professionals with knowledge in several areas, and acquisition of necessary skills and finally create the international educational teams, both in scientific, cultural, and artistic direction $[3 ; 4$, p. 3$]$.

As the trend of economic globalization is constantly accelerated and deepened, the problem of training qualified personnel at the international level has become more acute. After the strategy "One Belt - One Road" has been accepted, the construction of internationalization of higher education has become an important link in the development of higher education in China and the training of competitive personnel at the professional level [2, p. 121].

Chinese higher education experts directly link the success of cultural cooperation in the implementation of the "One Belt - One Road" strategy with the development of its economic component. In particular, the strengthening of international cooperation through cooperation in the cultural and artistic spheres determines the further development of economic cooperation. In its turn, in the economic sphere, the strategic idea of foreign and domestic policy "One Belt - One Road" helps regulate the economic structure and optimize industry. Innovative technologies, which are used due to the requirements formed by the strategic idea, are an important link in regulating the structure of industry and its sustainable development. This process of improving the efficiency of the economy in general and industry in particular leads to an increase in the need for highly qualified creative staff [6].

Taking into account the increased attention to the issue of internationalization, the ability to communicate in a foreign language has become one of the necessary requirements for specialists to be. The main goal is to form competitive personnel, which could take part in international projects without any language barrier.

It is pointed out that the study of foreign languages contributes not only to the increase of the level of students' knowledge, but it deepens the understanding of cultural diversity as well. Knowledge of a foreign language expands the international horizons of students, cultivates international consciousness, increases the ability to intercultural communication and develops the innovative potential of the individual.

Accordingly, it is emphasized that Chinese higher education and education management 
institutions should have highest regard for foreign language teaching. The practical implementation of this aspect we can see in teaching two foreign languages and the offer of optional disciplines to students.

In addition to teaching English, specialists in higher education in China emphasize the need to develop teaching of Russian or Ukrainian, as these countries are important strategic partners.

Highly qualified specialists of the cultural sector are defined as the key to a successful stimulation of strategic ideas of the New Silk Road policy "One Belt-One Road". Accordingly, it is generally accepted that in the process of economic development of the staffing is of major strategic importance and highly qualified creative cadre personnel is the elite of human resources [4].

In modern educational environment of the People's Republic of China it is indisputable that the strategic ideas of the policy "One Belt - One Road" provide a direct opportunity to effectively deepen and improve trade, economic, social and political relations between countries and create the necessary conditions for new multilateral international cooperation.

In this case, the primary importance is given to educational and cultural factors. In particular, it is believed that in order to establish productive ties with the countries involved, it is necessary to strengthen international partnerships, one of the most effective ways of which is the cooperation in the development of cultural relations. This task is accomplished, to a large extent, by the system of training and education of far-sighted highly qualified specialists, scientists, cultural figures and diplomats with international communication skills, which should be acquired primarily in the process of studying in higher education.

In the strategic idea of the "One Belt - One Road" policy, the problem of improving and deepening the system of education of diplomats and specialists in international organizations, including ones in the field of cultural cooperation, is accepted as extremely important. Thus, when stimulating strategic ideas of the "One Belt - One Road" policy, the training of highly qualified creatively oriented personnel is considered to be the most important factor. It should be emphasized that this strategy includes not only economic and socio-political components, but also the sphere of culture, the field of training of cultural and artistic figures [7].
In the official concept of China's higher education system, in particular in the part dedicated to the process of training highly qualified personnel, the personnel evaluation system should be transformed from "types of knowledge" to "types of abilities", i.e. the emphasis is primarily on the amount of accumulated information, as it used to be. It is characterictic that this applies not only to the training of specialists-to-be in the field of social, political and economic relations, but the specialists in the field of culture and art.

This means that the concept of education in Chinese universities is to be reformatted from the "examination" system to the quality education system. Particular attention in creating a new concept of education that meets the urgent needs of today, including in the cultural sphere, is paid to the construction of the educational process based on the development of personal abilities of students. It is reasonably believed that only in this way university students shall have real opportunities to gain free space for the development and enhancement of research and innovation skills, as well as creative and artistic achievements.

For the practical implementation of this process in order to improve the system of higher education and bring it into line with the requirements of modern society, a number of measures are provided to change the very structure of the educational process. In particular, it is believed that it is necessary to create an organizational structure of numerous matrices:

- matrix of a combination of scientific research with administrative and managerial work;

- a matrix of combining the process of study with research;

- a matrix of a combination of different projects and different academic disciplines.

It should be noted that the implementation of these matrices not only provides more opportunities for coordination between organizations, but also promotes the sharing of resources in research projects, and ultimately leads to improved results in the training of highly qualified creative staff.

At the same time, in the areas of the education system, higher education institutions, including institutions for the training of future specialists in the fields of culture and art, must adhere to the principle "Everything is for the student". In addition to traditional educational and scientific work, the emphasis is on the need to provide 
training programs that best meet the individual abilities of each of the future professionals, i.e. on the actualization of the personal approach to learning [5, p.16].

Directly in the process of educational process, in particular, in the field of organization of educational disciplines, it is necessary to provide the opportunity where there is more space for individual choice of the learning stratagy, including creative tasks. Along with this, it is believed that educational institutions should improve teaching systems in the field of organization of special education, provide opportunities to disseminate knowledge to study disciplines in various specialties, to educate innovation-oriented, and creatively aware staff.

However, on the other hand the Chinese government understand that only a highly professional academic staff is able to train professional specialists. The high professional level of the teaching and research staff is recognized as a necessary, integral part in the process of training specialists and highly qualified students. According to this, the formation of teachers and their professional development play an important role in the training of modern specialists in higher education.

It is emphasized that the teaching staff should try to keep up with innovative ways and methods of teaching disciplines. It is clear that nowadays it is necessary to train a specialist not only with good knowledge, but also the ability to use it in practice, to teach students to think independently, make decisions, work in groups, develop communication, artistic, creative abilities, take responsibility [2].

Thus, it can be concluded that higher education in China focuses on the implementation of the strategy "One Belt One Road", which aims to economic and cultural development of the country through the expansion of international cooperation with partner countries, including not only economic and social and political spheres, but also in the field of culture and arts. It is believed that the establishment of cultural interaction is a necessary prerequisite for effective economic, educational, scientific cooperation. Accordingly, at this stage of the development the training of highly qualified, internationally competitive specialists becomes especially important.

In its turn, this determines the need to improve the educational process in higher education, which is practically accomplished by strengthening a number of necessary elements, such as learning a foreign language, applying individual approach, mastering innovative technologies, developing international cooperation in the educational process, and deepening interdisciplinary connections.

\section{СПИСОК ВИКОРАСТИНИХ ДЖЕРЕЛ ТА ЛІТЕРАТУРИ:}

1. Chen Syue, Tsiyu Minfen. Opportunities and challenges in promoting the «One belt, one road» initiative in China. Journal of CREATIVE Economy. 2018. № 8. Р. 49-53

2. Бай Лу. Исследование пути интернационализации высшего образования при стратегии «Один поясодин путь». Новый запад. 2015. № 23. С. 115-132.

3. Ван Гоган. «Один пояс - один путь»: инновация концепции международной экономики на основании китайской традиционной культуры. Исследование международных финансов. 2015. Июль. С. 3-10.

4. Дударева Н. А. Интернационализация системы высшего образования: экспорт образовательных услуг. Вестник ИГЭУ. 2010. Вып. 1. С. 1-5.

5. Компетнісний підхід у сучасній освіті: світовий досвід та українські перспективи : Бібліотека з освітньої політики / під заг. ред. О. В. Овчарук. К. : К. І. С., 2004. 112 с.

6. Ли Синьюнь. Путь развития и трудности высшего образования в стратегии «Один пояс - один путь». Учебная газета. Нанкинский политехнический университет. 2016. С. 1-5.

7. Чжао Вэй. Шанс и вызов в строительстве «Один пояс - один путь» в Китае. Китайский рынок. 2015. № 43. C. 18.

8. 刘财气, 王曼丽。一代一路：中国软式力的 “西游”之路。讲汉论天, 2016, \#6, 48-52页

9. 黄琳覃。“一代一路”建设自需发挥文化软式力的现行作用。宁夏党校学报。2016, \#6, 80-83页 


\section{REFERENCES:}

1. Chen Syue, Tsiyu Minfen (2018). Opportunities and challenges in promoting the «One belt, one road» initiative in China. Journal of CREATIVE Economy. № 8. P. 49-53 (in English)

2. Bay Lu (2015). Issledovaniye puti internatsionalizatsii vysshego obrazovaniya pri strategii «Odin poyas- odin put» [Study of the way of internationalization of higher education according to the strategy "One Belt - One Road"]. Novij zapad. № 23. P. 115-132. (in Russian)

3. Van Gogan (2015). «Odin poyas - odin put`»: innovacziya konczepczii mezhdunarodnoj e konomiki na osnovanii kitajskoj tradiczionnoj kul'tury [ One Belt - One Road «: Innovation of the Concept of International Economy Based on Chinese Traditional Culture]. Issledovanie mezhdunarodny'kh finansov. Iyul'. P. 3-10. (in Russian)

4. Dudareva, N. A (2010). Internaczionalizacziya sistemy` vy`sshego obrazovaniya: e 'ksport obrazovatel’ny`kh uslug [Internationalization of the higher education system: export of educational services]. Vestnik IGE'U. 2010. Vy`p. 1. P. 1-5. (in Russian)

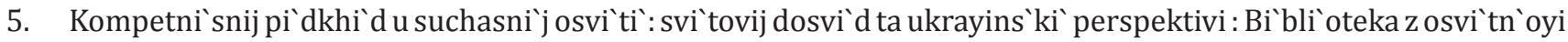
poli tiki (2004) [Competent insight from current education: world experience and the Ukrainian perspectives: Library of educational policy. Kyiv, K. I'. P. 112 p. (in Ukrainian)

6. Li Sin`yun`(2016). Put` razvitiya i trudnosti vy`sshego obrazovaniya v strategii «Odin poyas - odin put» [The development path and difficulties of higher education in the «One Belt - One Road» strategy]. Uchebnaya gazeta. Nankinskij politekhnicheskij universitet. P. 1-5. (in Russian)

7. Chzhao Vey (2015). Shans i vyizov v stroitelstve «Odin poyas - odin put» v Kitae [Chances and challenges in the development of One Belt-One Road]. Kitayskiy ryinok. 43. P. 18.

8. Lyu Czzajczi, Van Man'li (2016). «I daj i lu»: Chzhungo zhuan`shili de` «si yu» chzhi lu: [«One Belt, One Road : The Journey to the West» of China’s Soft Power]. Czzyankhan` lun `tan`. № 6. P. 48-52 (in Chinese)

9. Huan Lintan (2016). «I day i lu» tszyanshe tszi syuy fahuey venhua zhuanshli desyansin tszoyun : [Development of «One Built-One Road» badly needs the usage of a leading role of soft force culture]. Ninsya dansyao syuebao. № 6. P. 80-83. 